\section{Testing of Various Solvents for the Preparation of Lipid Samples for Use in Thin Layer Chromatography}

\author{
Antonia Odagiu - Gheorghe Sălăjan - Daniel \\ Mierliță - Bogdan Georgescu - Mariana Dinea \\ University of Agricultural Sciences and Veterinary Medicine, \\ Cluj-Napoca
}

\section{SUMMARY}

We analyzed the muscular tissue of 6 sheep. Lipid extraction was performed using the Handson and Olley method. TLC separation was performed using 4 separation systems and the best separation method was determined. Visualization was done using a mixture copper acetate and phosphoric acid, at $150^{\circ} \mathrm{C}$.

\section{INTRODUCTION}

The number of thin layer chromatography (TLC) techniques used for various lipids separation increased over the last decade. These new TLC techniques allow the separation of almost all major types of polar lipids through a single migration. In this way, it is now possible not only to qualitatively analyze polar lipids but, using densitometry in situ from chromatography plates, it is possible to perform very accurate quantitative analyses.

These new methods are very rapid and even more sensible than the classic ones that use, for example, bidimensional chromatography followed by phosphorus and galactose determinations. The lipid structure of muscle tissue in Turcana sheep from Romania has not received proper study as yet. The aim of our paper is to emphasize those systems that allow polar lipid separation and to establish an improved solvents system for TLC separation of polar lipids from Turcana sheep muscular tissue.

\section{MATERIAL AND METHOD}

A single sheep muscular tissue sample (dry matter) was used from five Turcana sheep individuals. We performed the extraction of the total lipids using the Handson and Olley method (1962) extraction with the mixture chloroform - methanol water, 2:2:1, v/v - (Hamilton and Rossel, 1986). The TLC separation was realized in a chromatographic chamber, using kieselgel TLC plates (produced by Merck, $10 \times 20 \mathrm{~cm}$ ), activated for 30 minutes at 100 ${ }^{\circ} \mathrm{C}$.

The solvents systems used were:

A: metil acetate - $\mathrm{n}$ - propanol - chloroform methanol - $\mathrm{KCl}$ aqueous solution, 0,25\% (25:25:28:10:7, v/v); [Bratt and Akerluna, 1994]

B: chloroform - methanol - acetate - water
(85:15:10:3,5, v/v); [Heape, et al., 1985]

$\mathrm{C}$ : metil acetate - izopropanol - chloroform methanol - $\mathrm{KCl}$ aqueous solution, 0,25\% (25:25:28:10:7, v/v); [Vittelo and Zanetta, 1978]

D: metil acetate - izopropanol - chloroform methanol - $\mathrm{KCl}$ aqueous solution, 0,25\% (25:25:25:10:7, v/v); [Vittelo and Zanetta, 1978].

In order to determine the main types of polar lipids, we used the $R_{f}$ values as a control for the above mentioned systems of solvents (Table 1).

Visualization was realized using a mixture copper acetate and phosphoric acid, at $150{ }^{\circ} \mathrm{C}$.

\section{RESULTS AND DISCUSSION}

The use of the four separation systems gave the best results only after a previous TLC separation of the polar lipids from the neutral lipids. As a separation system the mixture petroleum ether - ethyl ether - acetate (10:10:0.1, v/v) was used.

The results show that a higher proportion of chloroform in a mixture of solvents led to a lower value for $R_{f}$, for almost all polar lipids. The $R_{f}$ values obtained for the analysed samples (Table 2) are closer to those mentioned in the literature (Table 1) for the $\mathrm{C}$ solvents system. The method has a high repeatability.

\section{CONCLUSIONS}

1. The TLC separation of polar lipids is a rapid method for their qualitative analysis, allowing simultaneous performance of an accurate quantitative analysis, using densitometry.

2. The analysed Turcana sheep muscular tissue contains a high proportion of neutral lipids, emphasized by the necessity to separate them using a mixture of solvents with low polarity, in order to permit a clear separation of the remained polar lipids.

3. The best solvents system for qualitative separation of the polar lipids seems to be in our case (Turcana sheep muscular tissue) the C system. 


\section{REFERENCES}

Bratt, C. E.-Akerluna, M. E. (1994): Journal of Plant Physiology. 32. 2. 313-315.

Folch, I.-Lees, M.-Sloane-Stanley, G. A. (1957): Journal of Biology and Chemistry. 24. 1. 226, 497.

Hamilton, R. J.-Rossel, J. B. (1986): Analysis of oils and fats, London: Elsevier Applied Science Publishers. 22-50.

Heape, A. M.-Jaquelin, M.-Boiron, F.-Cassagne, C. (1985): Journal of Chromatography. 49. 3. 322, 391-395.

Vittelo, F.-Zanetta, I. P. (1978): Journal of Chromatography. 42. 1. 166, 637.

Table 1: $\mathbf{R}_{\mathbf{f}}$ for the main polar lipids

\begin{tabular}{|c|c|c|c|c|}
\hline \multirow{2}{*}{$\begin{array}{c}\text { Polar } \\
\text { lipids }\end{array}$} & \multicolumn{4}{|c|}{ Solvents system } \\
\cline { 2 - 5 } & A & \multicolumn{1}{|c|}{ B } & C & \multicolumn{1}{c|}{ D } \\
\hline SF & 0,08 & 0,22 & 0,09 & 0,07 \\
\hline PC & 0,10 & 0,28 & 0,11 & 0,09 \\
\hline PA & 0,32 & 0,52 & 0,40 & 0,38 \\
\hline PG & 0,38 & 0,37 & 0,45 & 0,43 \\
\hline PE & 0,42 & 0,45 & 0,51 & 0,50 \\
\hline
\end{tabular}

$\mathrm{R}_{\mathrm{f}}=$ resolution factor; $\mathrm{SF}=$ sphingolipids; $\mathrm{PC}=$ phosphatidilcoline; $\mathrm{PA}=$ phosphatidil-acetilamine; $\mathrm{PG}=$ phosphatidil glicerolamine; $\mathrm{PE}=$ phosphatidil - etanolamine
Table 2: $\mathbf{R}_{\mathbf{f}}$ for polar lipids from analysed Turcana sheep muscular tissue (average values)

\begin{tabular}{|c|c|c|c|c|c|}
\hline \multirow{2}{*}{ Sample } & \multirow{2}{*}{$\begin{array}{l}\text { Polar } \\
\text { lipids }\end{array}$} & \multicolumn{4}{|c|}{ Solvents system } \\
\hline & & $\mathbf{A}$ & B & $\mathbf{C}$ & D \\
\hline \multirow{5}{*}{1} & $\mathrm{SF}$ & 0,11 & 0,16 & 0,09 & 0,10 \\
\hline & $\mathrm{PC}$ & 0,14 & 0,28 & 0,11 & 0,15 \\
\hline & $\mathrm{PA}$ & 0,40 & 0,54 & 0,38 & 0,28 \\
\hline & PG & 0,54 & 0,40 & 0,44 & 0,54 \\
\hline & $\mathrm{PE}$ & 0,59 & 0,48 & 0,50 & 0,59 \\
\hline \multirow{5}{*}{2} & SF & 0,11 & 0,16 & 0,09 & 0,10 \\
\hline & PC & 0,14 & 0,28 & 0,11 & 0,15 \\
\hline & $\mathrm{PA}$ & 0,40 & 0,54 & 0,38 & 0,28 \\
\hline & PG & 0,54 & 0,40 & 0,44 & 0,54 \\
\hline & $\mathrm{PE}$ & 0,59 & 0,48 & 0,50 & 0,58 \\
\hline \multirow{5}{*}{3} & SF & 0,11 & 0,16 & 0,09 & 0,10 \\
\hline & PC & 0,17 & 0,28 & 0,11 & 0,15 \\
\hline & $\mathrm{PA}$ & 0,40 & 0,54 & 0,38 & 0,28 \\
\hline & PG & 0,54 & 0,40 & 0,45 & 0,54 \\
\hline & $\mathrm{PE}$ & 0,59 & 0,48 & 0,50 & 0,59 \\
\hline \multirow{5}{*}{4} & SF & 0,11 & 0,16 & 0,09 & 0,10 \\
\hline & $\mathrm{PC}$ & 0,14 & 0,27 & 0,11 & 0,13 \\
\hline & $\mathrm{PA}$ & 0,41 & 0,54 & 0,38 & 0,29 \\
\hline & PG & 0,54 & 0,40 & 0,44 & 0,54 \\
\hline & $\mathrm{PE}$ & 0,58 & 0,47 & 0,50 & 0,57 \\
\hline \multirow{5}{*}{5} & SF & 0,12 & 0,16 & 0,09 & 0,10 \\
\hline & $\mathrm{PC}$ & 0,14 & 0,28 & 0,11 & 0,13 \\
\hline & $\mathrm{PA}$ & 0,40 & 0,54 & 0,38 & 0,30 \\
\hline & PG & 0,54 & 0,40 & 0,44 & 0,54 \\
\hline & $\mathrm{PE}$ & 0,59 & 0,48 & 0,50 & 0,59 \\
\hline
\end{tabular}

